\title{
In Vitro A- Glucosidase Inhibitory and In Vivo Glucose Digestion Activities of Ethanol Leaf Extract of Acalypha Wilkesiana in Normoglycaemic Rats
}

\author{
Anthony 0 Iyamu $^{1}$, Harrison 0 Otamere ${ }^{2}$ and Uwaifoh Akpamu*3 \\ ${ }^{1}$ Department of Medical Biochemistry, Faculty of Basic Medical Sciences, College of Medicine, Nigeria \\ ${ }^{2}$ Department of Physiology, Faculty of Basic Medical Sciences, College of Medicine, Nigeria \\ ${ }^{3}$ Gastrointestinal Secretory and Inflammatory Unit, Department of Physiology, Faculty of Basic Medical Sciences, College of Medicine, \\ Nigeria \\ *Corresponding author: Akpamu Uwaifoh, Department of Physiology, Faculty of Basic Medical Sciences, College of Medicine, \\ Nigeria
}

ARTICLE INFO

Received: 㓞 June 26, 2020

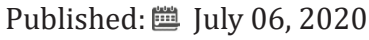

Citation: Anthony O Iyamu, Harrison 0 Otamere, Uwaifoh Akpamu. In Vitro AGlucosidase Inhibitory and In Vivo Glucose Digestion Activities of Ethanol Leaf Extract of Acalypha Wilkesiana in Normoglycaemic Rats Biomed J Sci \& Tech Res 28(4)-2020. BJSTR. MS.ID.004688.

Keywords: Acalypha wilkesiana; Normoglycaemic Rats; In vitro $\alpha$ - glucosidase inhibition; In vivo glucose digestion
ABSTRACT

We observed the ethanol leaf extract of Acalypha wilkesiana to be a rich source of phytochemicals and vitamins of therapeutic benefits. Considering the search for medicinal plants and products with hypoglycemic potentials, we conducted in vitro and in vivo studies to respectively investigate $\alpha$ - glucosidase inhibitory and glucose digesting activities of $A$. wilkesiana extract. The $\alpha$-glucosidase inhibitory activity was determined following previously described methods at concentrations of $0.1-0.9 \mu \mathrm{g} /$ $\mathrm{mL}$ using acabose as standard drug. Oral glucose tolerance test was determined in 24 normoglycemic adult male Wistar rats of $(140-160 \mathrm{~g})$ weight, assigned to four groups (n=6). At 0 minute, Group1 (control) and 2 (glucose treated) received $10 \mathrm{ml} /$ $\mathrm{kg} \mathrm{mL}$ distilled water while 3 (standard hypoglycemic treated) and 4 (A.wilkesiana extract treated) received glimepiride $(0.1 \mathrm{mg} / \mathrm{kg})$ and $A$. wilkesiana extract $(250 \mathrm{mg} /$ $\mathrm{kg})$ respectively. 30 minutes after, group 1 received distilled water $(10 \mathrm{ml} / \mathrm{kg} \mathrm{mL})$ while groups 2, 3 and 4 received $5 \%$ glucose water $(10 \mathrm{ml} / \mathrm{kg})$ and blood glucose level measured at 30 minutes interval for 180 minutes. The results showed a dose dependent $\%$ inhibition of $\alpha$ - glucosidase activity from $51.12 \pm 0.14$ to $58.01 \pm 0.11$ with acarbose and $50.48 \pm 0.29 \%$ to $56.14 \pm 0.56 \%$ with ethanol leaf extract of $A$. wilkesiana. A. wilkesiana $(69.50 \pm 4.71 \mathrm{mg} / \mathrm{dl} ; \mathrm{p}<0.05)$ and glimepiride $(74.33 \pm 5.10 \mathrm{mg} /$ $\mathrm{dl}$; $>0.05$ ) administrations concealed the rise in blood glucose following glucose loading $(97.67 \pm 3.25 \mathrm{mg} / \mathrm{dl})$ and significantly lowered blood glucose levels compared with the glucose treated group at 30 through 180 minutes. These findings suggest that ethanol leaf extract of $A$. wilkesiana possesses hypoglycemic potentials by inhibiting $\alpha$ - glucosidase activity and increasing glucose digestion or inhibiting absorption in normoglycemic rats.

\section{Introduction}

Metabolic syndrome is a cluster of several metabolic abnormalities, including central obesity, insulin resistance, hypertension, dyslipidemia, and hyperglycemia, that has become a major public health challenge [1]. Though different types of oral hypoglycemic agents are available along with insulin for the treatment of diabetes, there is an increase demand by patients to use the natural products with anti-diabetic activity

[2]. Interestingly, medicinal plants are now increasingly used in most parts of the world as hypoglycemic [3-7]. The high cost, low availability, uncertainty of use during pregnancy and undesirable side effects of synthetic drugs have been some of the factors leading to a strong preference for hypoglycemic drugs of plant origin, which are believed to be suitable for hyperglycemia treatments [8]. Herbal products can improve glucose metabolism and the overall 
condition of individuals with diabetes, not only by hypoglycemic effects, but also by improving lipid metabolism, antioxidant status and capillary function [9]. In our recent investigation, we observed the ethanol leaf extract of Acalypha wilkesiana to be a rich source of phytochemicals, macro-elements and vitamins known to have several therapeutic benefits [10]. Though this plant is not edible, it is found to contain alkaloids, tannins, resins [11] as well as plenty of terpenoids and vitamin $\mathrm{C}$ and moderate level of flavonoids [10]. The plant has wide uses in the traditional treatment of bacterial and fungal skin infections, neonatal jaundice, gastrointestinal disorders and malaria [12,13], antiparasitic and analgesic [14], possess antimicrobial $[15,16]$, antihypertension $[17,18]$, anticarcinogenic properties [19]. Its antihyperglycemic, antihyperlipidemic and ameliorative role on electrolytes disturbances have been demonstrated in diabetic mice [20]. According to El-Khateeb et al. [21], not much pharmacological research has been carried out on A. wilkesiana despite its importance in traditional medicine. Therefore, this study investigates the in vitro and in vivo $\alpha$ glucosidase inhibitory and glucose digestion activities of ethanol leaf extract of $A$. wilkesiana using normoglycemic adult male Wistar rats.

\section{Materials and Methods}

\section{Collection, Processing and Extraction of Plant Materials}

Samples of Acalypha wilkesiana leaves were collected from Benin City, Nigeria and authenticated at the Herbarium Unit of Forestry Research Institute, Ibadan, Nigeria. The leaves were sorted, air-dried for 7 days and then pulverized and packaged in polyethene air tight bags. $200 \mathrm{~g}$ of the powder leave was added into a container containing $1.5 \mathrm{~L}$ of $70 \%$ ethanol and used to prepare the ethanolic extract as described in Majekodunmi and Nubani [22] with few modifications.

\section{In Vitro Anti-Diabetic Activity of Ethanolic Leaves Extract of $A$. Wilkesiana}

The $\alpha$-glucosidase inhibitory activity of the ethanol leaf extract of $A$. wilkesiana was determined as described by Shai et al. [23] with slight modifications. Briefly, ethanol leaf extract of $A$. wilkesiana or acarbose at different concentrations $(0.1-0.9 \mu \mathrm{g} / \mathrm{mL})$ was incubated with $500 \mu \mathrm{L}$ of porcine pancreatic amylase $(2 \mathrm{U} / \mathrm{mL})$ in phosphate buffer ( $100 \mathrm{mM}, \mathrm{pH} 6.8$ ) at $37^{\circ} \mathrm{C}$ for 20 minutes. $250 \mu \mathrm{L}$ of $1 \%$ starch dissolved in $100 \mathrm{mM}$ phosphate buffer ( $\mathrm{pH}$ 6.8) was added to the reaction mixture and incubated at $37^{\circ} \mathrm{C}$ for 1 hour. Dinitrosalicylate colour reagent $(1 \mathrm{~mL})$ was added and boiled for 10 minutes. The absorbance of the resulting mixture was read at $540 \mathrm{~nm}$ and the inhibitory activity was expressed as percentage of a control without the inhibitors. All assays were carried out in triplicate. The inhibitory activities of the fractions on the $\alpha$-glucosidase were calculated using the following formula:

Inhibitory activity $\%=(1-[\mathrm{AS} / \mathrm{AC}]) \times 100$
Whereas is the absorbance in the presence of the sample and Ac is the absorbance of the control.

\section{Experimental Animals}

Twenty-four (24) adult male Wistar rats with average weight of 140-160g were obtained from the Animal House of the College of Medicine, Ambrose Alli University, Ekpoma. They were housed at room temperature on a 12 hour dark-light cycle and acclimatized for a 14-day period with ad libitum access to clean water and food (rat chow; Vital Feed Nig. Ltd, Jos, Nigeria).

\section{Oral Glucose Tolerance Test in Normoglycemic Rats}

The 24 rat which were normoglycemic were used for the study after acclimatizing for two weeks. They were fasted overnight for 12 hours before the experiment. Their fasting blood glucose levels were determined using Accu-check glucometer by Roche Diagnostic and then divided to four groups $(\mathrm{n}=6)$ as follows:

a. Group1: Negative control group; received $10 \mathrm{ml} / \mathrm{kg}$ of distilled water and another $10 \mathrm{ml} / \mathrm{kg} \mathrm{mL}$ of distilled water after 30 minutes.

b. Group 2: Positive control group; received $10 \mathrm{ml} / \mathrm{kg}$ of distilled water and $10 \mathrm{ml} / \mathrm{kg}$ of $5 \%$ glucose water after 30 minutes.

c. Group 3: Standard drug treated group; received $0.1 \mathrm{mg} /$ $\mathrm{kg}$ of Glimepiride; a standard anti-diabetic drug, and $10 \mathrm{ml} / \mathrm{kg}$ of $5 \%$ glucose water after 30 minutes.

d. Group 4: Extract treated group; received $250 \mathrm{mg} / \mathrm{kg}$ ethanol leaf extract of Acalypha wilkesiana and $10 \mathrm{ml} / \mathrm{kg}$ of $5 \%$ glucose water after 30 minutes.

The blood glucose levels were measured at $0,30 \mathrm{~min}, 60 \mathrm{~min}$, $90 \mathrm{~min}, 120 \mathrm{~min}, 150 \mathrm{~min}$ and $180 \mathrm{~min}$ after glucose loading. The mean increment of glyceamia in each group was calculated as the sum of increases in blood glucose divided by the number of animals after each period according to the method of Madar [24]. Data were expressed in means \pm SEM. Paired sample " $t$ "-test and one-way analysis of variance (ANOVA) was used to compare the group means between treatments in the in vitro and in vivo studies respectively. Differences were considered significant when $\mathrm{P} \leq 0.05$.

\section{Results}

Figure 2 compares the $\alpha$-glucosidase inhibitory activities of varying concentrations of the ethanol leaf extract of $A$. wilkesiana and acarbose. There was dose dependent \% inhibition of $\alpha$ glucosidase activity from $51.12 \pm 0.14 \%$ to $58.01 \pm 0.11 \%$ with acarbose and from $50.48 \pm 0.29 \%$ to $56.14 \pm 0.56 \%$ with the ethanol leaf extract of $A$. wilkesiana. The percentage $\alpha$ - glucosidase inhibitory activities was significantly higher $(\mathrm{p}<0.05)$ in the acarbose compared with the ethanol leaf extract at all doses but was similar at doses of $0.01 \mu / \mathrm{ml}(51.12 \pm 0.14 \%$ vs. $50.48 \pm 0.29 \%$; $\mathrm{p}>0.05)$ and $0.09 \mu / \mathrm{ml}(58.01 \pm 0.11 \%$ vs. $56.14 \pm 0.56 \% ; \mathrm{p}>0.05)$. 
Figure 3 demonstrates the time course of oral glucose tolerance in normoglycermic rats treated with ethanol leaf extract of $A$. wilkesiana compared with standard drug and controls after glucose loading. Baseline glucose levels were similar in all the groups 30 minutes before glucose loading. Blood glucose level increased in the distilled water + glucose $(97.67 \pm 3.25 \mathrm{mg} / \mathrm{dl})$ treated 30 minutes after glucose loading but the administration of both $250 \mathrm{mg} / \mathrm{kg}$ ethanol leaf extract of $A$. wilkesiana $(69.50 \pm 4.71 \mathrm{mg} / \mathrm{dl} ; \mathrm{p}<0.05)$ and $0.1 \mathrm{mg} / \mathrm{kg}$ glimepiride $(74.33 \pm 5.10 \mathrm{mg} / \mathrm{dl} ; \mathrm{p}>0.05)$, concealed the rise in glucose level. Compared to the control $(83.33 \pm 2.22 \mathrm{mg} /$ dl) treated with only distilled water, blood glucose level was also lower in the extract and standard drug treated groups. Compared with distilled water + glucose treated group, blood glucose levels were significantly lower in the extract and standard drug treated groups by 30 through 180 minute after glucose loading. Although not significant, blood glucose was lower in the extract treated compared with the standard drug by 30 through 180 minutes.

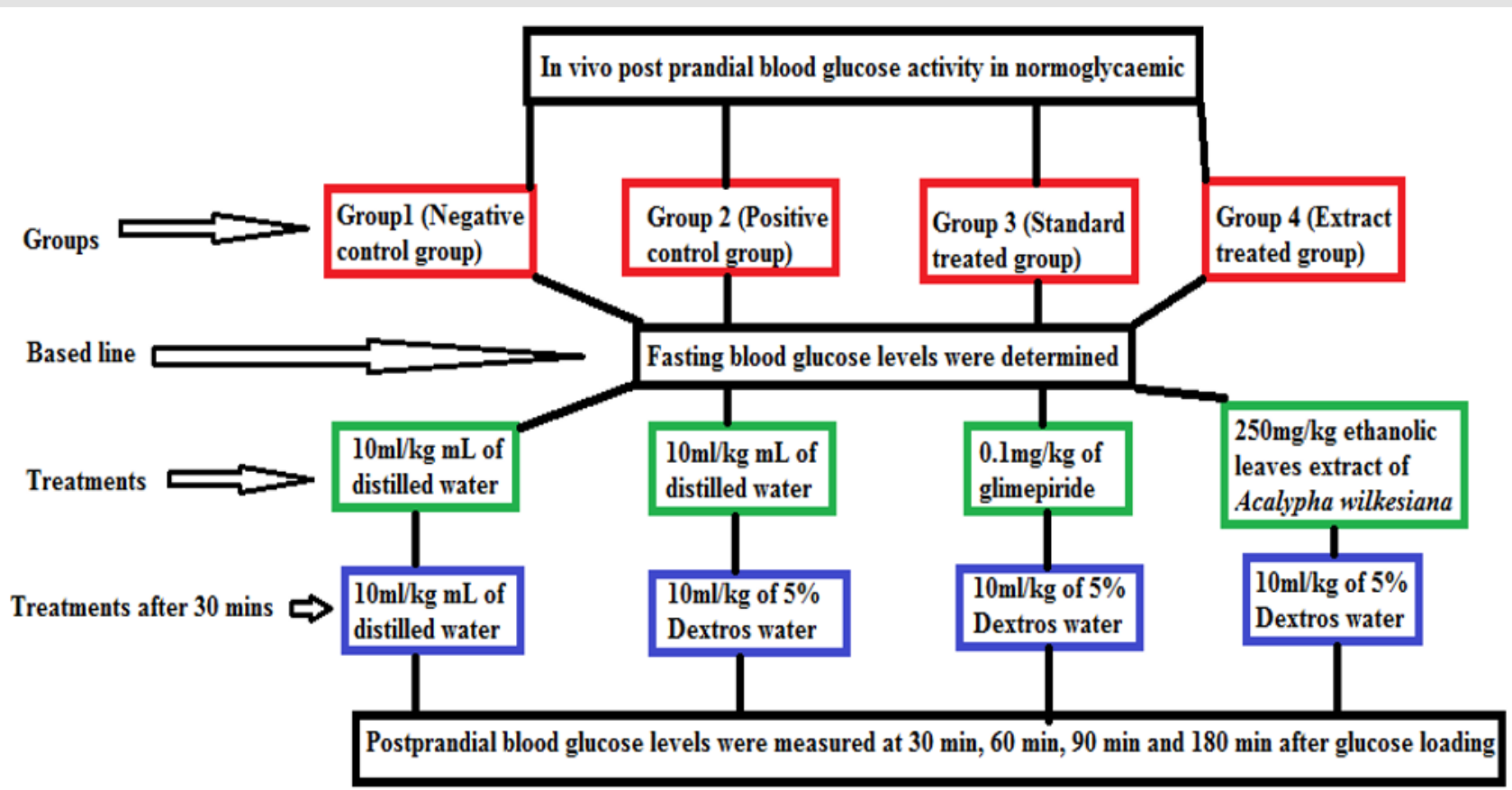

Figure 1: Schematic representation of the grouping of normoglycermic rats.

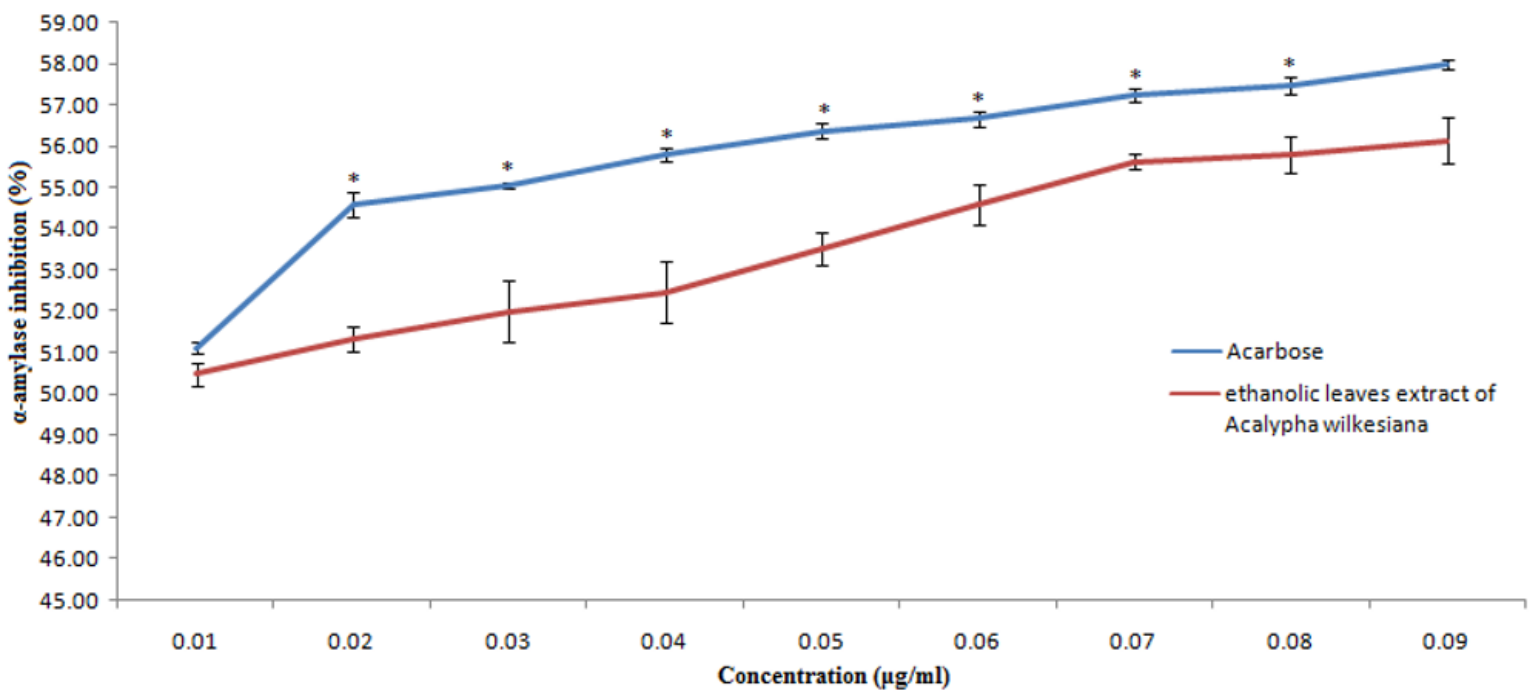

Figure 2: In vitro a- glucosidase inhibitory activities of acarbose compared with ethanolic leaves extract of $A$. wilkesiana. Values are Mean \pm SEM in triplicate.

* Indicates significant difference at $\mathrm{p}<0.05$ (paired sample " $\mathrm{t}$ "-test). 


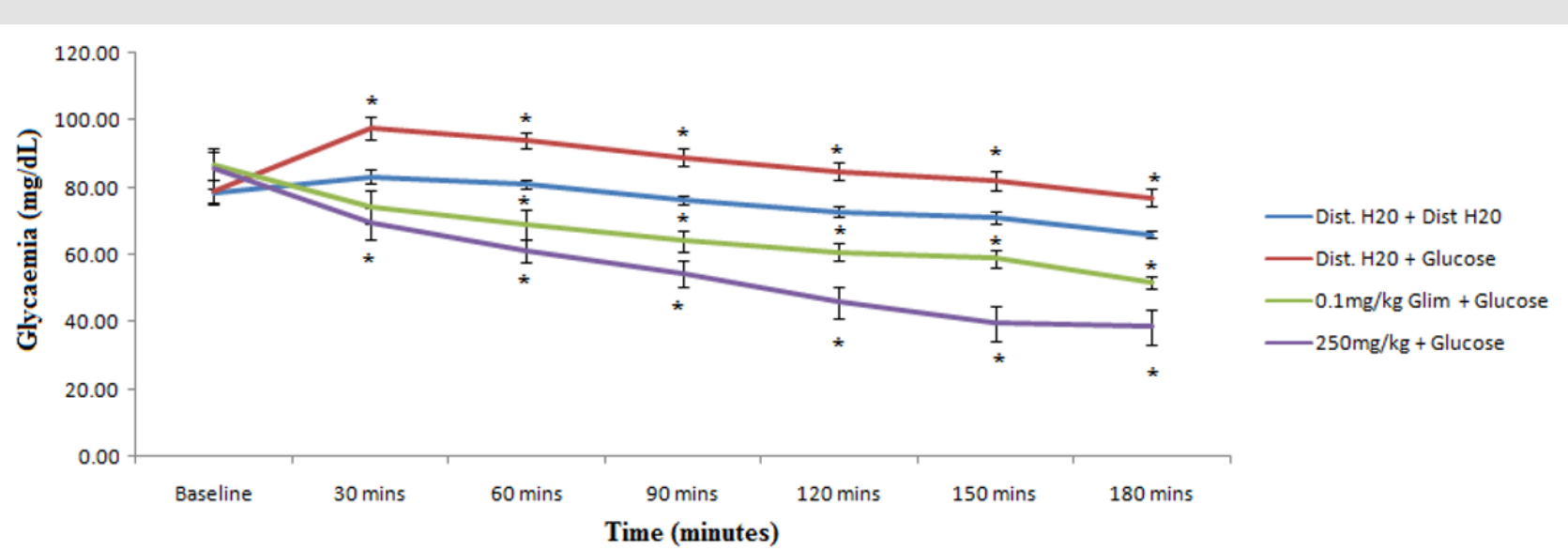

Figure 3: Time course of oral glucose tolerance in the controls, standard drug and ethanolic leaves extract of A. wilkesiana treatments in normoglycaemic rats.

Values are Mean \pm SEM, $(\mathrm{n}=6$ rats),

* indicates significant difference at $\mathrm{p}<0.05$ compared with untreated control (water treated). $\mathrm{H} 2 \mathrm{O}=$ water, Dist $=$ distilled, Glim

$=$ Glimepiride treated, $250 \mathrm{mg} / \mathrm{kg}=$ Acalypha wilkesiana treated.

\section{Discussion}

The major goal in diabetes management is the near normal maintenance of fasting and postprandial blood glucose levels [25]. In fact, Matsui et al. [26] and Wassmann and Nickenig [27], suggested suppression of glucose absorption via inhibition $\alpha$-amylase or $\alpha$-glucosidase enzymes inhibition as therapeutic approach to postprandial hyperglycaemia. In the present study, varying concentrations of ethanol extract of $A$. wilkesiana leaves presented similar promising impact in in vitro inhibition of $\alpha$-glucosidase with acarbose; a standard diabetic drug (Figure 2). This finding suggests the ethanol leaf extract of $A$. wilkesiana to have digestibility action on glucose similar to acarbose. This assertion is based on the fact that $\alpha$ - glucosidase is involve in the digestion of starch into various oligosaccharides, and disaccharides to produce glucose and other monosacharides [28]. In support of this finding, Fonkoua et al. [29] has reported similar findings with hydroethanolic extract of $A$. wilkesiana but reported no effect with aqueos extract. Both murine model [30] and clinical [31] studies have shown inhibitors of $\alpha$-amylase and $\alpha$-glucosidase suppress the production and absorption of glucose in the small intestine. Acarbose is a complex oligosaccharide that binds competitively to the $\alpha$-glucosidases at the brush border of the small intestine to delay sucrose and starch breakdown and the absorption of glucose and fructose [32]. This drug has proven efficacious in reducing post-prandial increases in glucose and insulin [33]. Thus, the observed finding from the present study indicates the ethanolic leaves extract of $A$. wilkesiana can be a promising drug for postprandial glucose suppression through delaying sucrose and starch breakdown or inhibiting absorption of glucose. In the in vivo study, $250 \mathrm{mg} / \mathrm{kg}$ ethanolic leave extract of $A$. wilkesiana cause a decrease in postprandial blood glucose level after glucose loading in normoglycermic rats. The observed suppression of glucose level after glucose loading by $250 \mathrm{mg} / \mathrm{kg}$ ethanolic leave extract of $A$. wilkesiana in normoglycemic indicates the extract to have glucose reducing properties. Martin et al. [29] has reported hypoglycaemic effect of $400 \mathrm{mg} / \mathrm{kg}$ hydroethanolic extract of $A$. wilkesiana in streptozotocin diabetic rats. However, Al-Attar [20] reported orally aqueous $A$. wilkesiana leaves extract to cause a duration dependent decrease in blood glucose in streptozotocin induced diabetic rats.

\section{Conclusion}

Overall, this study showed that ethanolic leave extract of $A$. wilkesiana possesses hypoglycemic activity in normaglycemic state. Since a similar dose dependent difference was observed between $A$. wilkesiana leaves extract and acarbose in suppressing $\alpha$ - glucosidase, A. wilkesiana leaves extract therefore showed hypoglycemic potential via the inhibition of $\alpha$ - glucosidase and stimulation of glucose digestion mechanisms.

\section{References}

1. Alberti KG, Zimmet P, Shaw JIDF (2005) Epidemiology Task Force Consensus Group The metabolic syndrome-a new worldwide definition. Lancet 366(9491): 1059-1062.

2. Venkateswaran S, Pari L, Suguna L, Chandrakasan G (2003) Modulatory Effect of Coccinia indica on Aortic Collagen in Streptozotocin-Induced Diabetic Rats. Clinical and Experimental Pharmacology and Physiology 30(3): 157-163.

3. Osadebe PO, Okide GB, Akabogu IC (2004) Study on antidiabetic activities of crude methanolic extracts of Loranthusmicranthus (Linn) sourced from five different host trees. J Ethnopharmacol 95(2-3): 133138.

4. Ezugwu CO, Odoh UE, Ajali U (2005) Blood sugar lowering effect of gum extract of Mucuna sloanei Fawc. and Randle (Fam. Papillionaceae) seed. Biol Res 3(2): 49-51.

5. Patel VS, Chitra V, Lakshmi Prasanna P, Krishnaraju V (2008) Hypoglycemic effect of aqueous extract of Parthenium hysterophorus L. in normal and alloxan induced diabetic rats. Indian J Pharmacol 40(4): 183-185. 
6. Yadav JP, Saini S, Kalia AN, Dangi AS (2008) Hypoglycemic and hypolipidemic activity of ethanolic extract of Salvadoraoleoides in normal and alloxan induced diabetic rats. Indian J Pharmacol 40: 23-27.

7. Odoh UE, Ezugwu CO, Ezejiofor M (2013) Anti-diabetic and toxicological studies of the alkaloids of Acanthus montanus (Acanthaceae) leaf. Int Curr Res 5(12): 4249-4255.

8. Okigbo RN, Mmeka EC (2006) An appraisal of phytomedicine in Africa KMITL Sci Tech J 6(2): 83-94.

9. Chan CH, Ngoh GC, Yusoff R (2012) A brief review on anti diabetic plants: Global distribution, active ingredients, extraction techniques and acting mechanisms. Pharmacogn Rev 6(11): 22-28.

10. Rahmatullah M, Das AK, Mollik MAH, Jahan R, Khan M, et al. (2009) Am Eurasian. J Sustain Agric 3(4): 881-888.

11. Akinde BE, Odeyemi 00 (1987) Extraction and microbiological evaluation of the oils from the leaves of Acalypha wilkesiana. Nig Med J 17: 163-165.

12. Ogundaini AO (2005) An Inaugural Lecture Delivered at Oduduwa Hall, Obafemi Awolowo University Ile-Ife, Nigeria. Inaugural Lecture Series 176, OAU Press Limited, Ile-Ife, Nigeria p. 12-15

13. Udobang JA, Nwafor PA, Okokon JE (2010) Analgesic and antimalaria activities of crude leaf extract and fractions of Acalypha wilkesiana. J Ethnopharmacol 127(2): 373-378.

14. Akinyemi KO, OK Oluwaans, EO Omomigbehin (2006) Antimicrobial activity of crude extracts of three medicinal plants used in south-western Nigerian folk medicine on some food borne bacterial pathogens. Afr J Tradit Compl Altern Med 3(4): 13-22.

15. Gotep JG, Agada GOA, Gbise DS, Chollom S (2010) Antibacterial activity of ethanolic extract of Acalypha wilkesiana leaves growing in Jos, Plateau State, Nigeria. Malaysian J Microbiol 6(2): 69-74.

16. Nworgu ZAM, Ameachina FC, Owolabi J, Otokiti I, Ogudu U (2011) Cardiovascular effects of aqueous extract of Acalypha wilkesiana Hoffmannii leaves in rabbits and rats. Nig J Pharm Sci 10(2): 45-50.

17. Ikewuchi JC (2013) Moderation of hematological and plasma biochemical indices of sub-chronic salt-loaded rats, by an aqueous extract of the leaves of Acalypha wilkesiana “Godseffiana” MuellArg (Euphorbiaceae). Asian Pac J Trop Med 6(1): 37-42.

18. Lim SW, Loh HS, Ting KN, Bradshaw TD, Zeenathul NA (2013) Acalypha wilkesiana ethyl acetate extract enhance the in vitro cytotoxic effect of alpha-tocopherol in human brain and lung cancer cells. Int J Biosci Biochem Bioinforma 3(4): 335-340.

19. Al Attar AM (2010) Physiological Study on the Effect of Acalypha wilkesiana leaves extract on streptozotocin-induced experimental diabetes in male mice. Am Med J 1(1): 51-58.

ISSN: $2574-1241$

\section{DOI: 10.26717/BJSTR.2020.28.004688}

Uwaifoh Akpamu. Biomed J Sci \& Tech Res

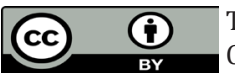

This work is licensed under Creative Commons Attribution 4.0 License

Submission Link: https://biomedres.us/submit-manuscript.php
20. El Khateeb YA, Eid Azzaz AN, Mahmoud IH (2014) Phytochemical constituents, hypoglycemic and haematological effects of methanolic Acalypha wilkesiana leaves extract on streptozotocin-induced diabetic rats. European Journal of Chemistry 5(3): 430-438.

21. Majekodunmi SO, Nubani SE (2014) Formulation of Acalypha wilkesiana Muell Arg Ethanol leaf extract into creams for the treatment of microbial microbial skin infections. International Journal of Pharma Pharmacycological Science 31(10): 45-53.

22. Madar Z (1989) The effect of acarbose and miglitol (BAY-M-1099) on postprandial glucose levels following ingestion of various sources of starch by non diabetic and streptozotocin induced diabetic rats. J Nutr 119(June): 2023-2029.

23. Bailey CJ (2009) Potential new treatments for type 2 diabetes. Trends in pharmacological sciences 21 (7): 259-265

24. Matsui T, Tanaka T, Tamura S, Toshima A, Miyata Y, et al. (2007) Alpha glucosidase inhibitory profiles of catechins and theaflavins. Journal of Agricultural and Food Chemistry 55: 99-105.

25. Wassmann K, Nickenig G (2004) Modulation of oxidant and ant-oxidant enzyme expression and function in vascular cells. Hypertension 44(4): 381-386.

26. Bhandari MR, Jong Anurakkun N, Hong G, Kwabata J (2008) Alpha glucosidase and alpha amylase inhibitory activities of Nepalese medicinal herb Pakhanbhed (Bergenia ciliate, Haw.). Food Chemistry 106: $247-252$

27. Fonkoua M, Ngaluh J, Edoun EFL, Mbah NL, Mbouobda HD, et al. (2017) Screening of antioxidant and antidiabetic properties of aqueous and hydroethanolic extracts of the leaves of Acalypha wilkesiana Muel Arg. American Journal of Pharmacy \& Health Research 5(6): 78-88.

28. Kaur C, kapoor H (2002) Antioxidant activity and total phenolic content of some Asian vegetables. International Journal of Food Sciences and Technology 37: 153-161.

29. Smith C, Marks AD, Lieberman M (2005) Marks's Basic Medical Biochemistry: A Clinical Approach, $2^{\text {nd }}$ (Edn.). Lipincott Williams \& Wilkins, Baltimore, Maryland 21201-2436 USA.

30. Salemi Z, Rafie E, Goodarzi TM, Ghaffari M (2016) Effect of Metformin, Acarbose and Their Combination on the Serum Visfatin Level in Nicotinamide/Streptozocin-Induced Type 2 Diabetic Rats. Iran Red Crescent Med J 18(3): e23814.

31. Hanefeld M, Fischer S, Schulze J, Spengler M, Wargenau M, et al (1991) Therapeutic potentials of acarbose as first-line drug in NIDDM insufficiently treated with diet alone. Diabetes Care 14(8): 732-737.

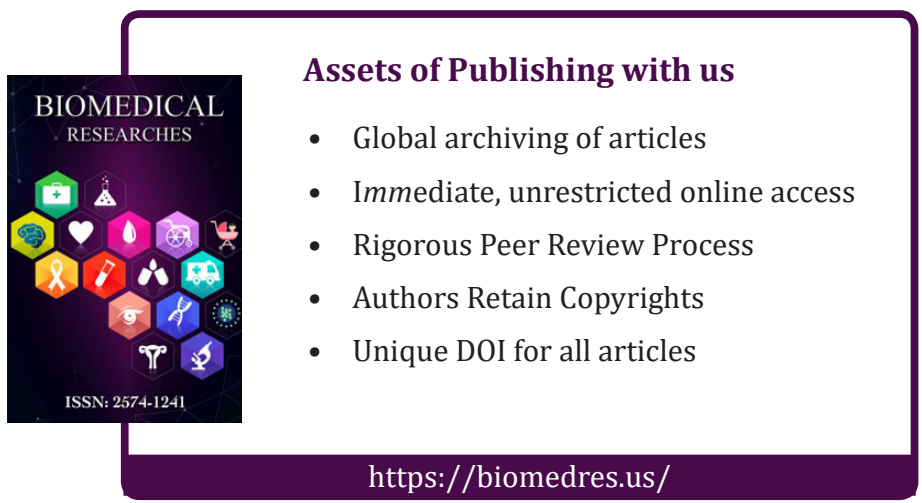

